\title{
Od demokracji bezpośredniej do rządów zgromadzenia? Rousseau i problemy republikańskiego konstytucjonalizmu*
}

\section{WPROWADZENIE}

Na pierwszy rzut oka, zasady demokracji bezpośredniej i tzw. rządów zgromadzenia wydają się mieć zbliżone założenia doktrynalne. Każdą z tych reguł można odczytać w duchu silniej pojętej idei suwerenności ludu. Rządy zgromadzenia byłyby w tym względzie bardziej rozwiniętą formą rządów ludu-obywateli, przenoszących - w warunkach dużych państw, uniemożliwiających przeprowadzenie bezpośrednich zgromadzeń - przynależne im uprawnienia prawodawcze (i kontrolne - względem urzędników wykonawczych) na obranych przedstawicieli, którzy musieli się cieszyć mandatem zaufania obywatelskiego ${ }^{1}$. Istotnie, patrząc z bardziej ogólnej perspektywy, obie te formuły ustrojowe łączy republikańskie przekonanie o potrzebie możliwie najbardziej czytelnego przełożenia woli narodu, pojętego czy to w sposób literalny, czy też bardziej abstrakcyjny - na decyzje władz publicznych. Te ostatnie nie posiadały wszak żadnej innej legitymacji poza tą, która wynikała z powszechnego umocowania ze strony ludu, nietracącego nigdy swych (przysługujących mu wyłącznie) praw zwierzchnich, czyli - zgodnie z najbardziej rozstrzygającym ujęciem Jeana-Jacques’a Rousseau - właśnie uprawnień prawodawczych. Zagadnienie to przy bliższym wejrzeniu okaże się

\footnotetext{
* Artykuł powstał dzięki badaniom sfinansowanym ze środków statutowych Wydziału Pedagogicznego Akademii Ignatianum w Krakowie.

1 Podobny kierunek ewolucji ustrojowej zdawał się potwierdzać częściowo przypadek Szwajcarii. Paul Bastid, zaliczający ten ustrój do przykładów rządów zgromadzenia, wskazywał mimo to na ważne $\mathrm{w}$ tym względzie ograniczenia, wynikające przede wszystkim z przyjęcia w Szwajcarii - właśnie - instytucji „bezpośredniej interwencji ludu” (zob. idem, Le gouvernement d'assemblée, Paris 1956, s. 303).
} 
jednak bardziej problematyczne. Trzeba wszak pamiętać, że sam Rousseau był bezwzględnym krytykiem zasady przedstawicielstwa, a przecież komentowana idea rządów zgromadzenia zakłada zasadniczo jej przyjęcie. Rozważane tu przejście od rządów bezpośrednich do rządów zgromadzenia wiązałoby się z uznaniem potrzeby reprezentacji. Zasadę tychże rządów przypisuje się przecież przede wszystkim systemom parlamentarnym, a dokładniej, wiąże wprost z warunkami pełnej dominacji ciała przedstawicielskiego nad pozostałymi gałęziami władzy, W szczególności egzekutywą, podporządkowaną mu całkowicie lub wręcz przejętą przez nie w całości². Co więcej, łatwo także zauważyć, że tak pojęty system rządów zgromadzenia wiąże się z odrzuceniem samej zasady podziału władz, na którą równie silnie nalegał Rousseau, przestrzegając przed pomieszaniem władzy suwerennej ludu z funkcjami wykonawczymi, oddawanym przecież odrębnym od zgromadzeń urzędom (urzędnikom).

Wszystkie te okoliczności i zastrzeżenia podpowiadają zatem wyraźnie, iż powiązania między przywoływanymi w tytule zasadami nie są aż tak oczywiste. W niniejszym artykule twierdzę mimo to, że, biorąc za punkt wyjścia bardziej ogólne rozumienie ideału rządów zgromadzenia, niewymagających z definicji wprowadzenia ściśle pojętych (tj. kojarzonych z zasadą mandatu wolnego) instytucji przedstawicielstwa ani też odrzucenia zasady podziału władz (o ile nie implikowała reguły równowagi tychże), można w sposób uzasadniony mówić o wiążącym je powinowactwie już w obrębie myśli Rousseau. Przyglądając się zwłaszcza rozwojowi tej ostatniej, możliwemu w każdym razie do odtworzenia dzięki porównaniu treści Umowy spolecznej i Uwag o rządzie polskim, będzie nawet można mówić o dopuszczalnym na gruncie właściwego dla Rousseau konstytucjonalizmu przeniesieniu akcentu z instytucji demokracji bezpośredniej na instytucje rządów zgromadzenia, wręcz o akceptacji swoistego sejmowładztwa, lecz zarazem nie doprowadzi to do odejścia od ideałów bardziej bezpośrednich rządów obywatelstwa. W tym świetle będzie można inaczej spojrzeć na samo zagadnienie relacji między najważniejszymi zasadami ustrojowymi zachodniego konstytucjonalizmu.

\section{ZASADY ZWIERZCHNICTWA LUDU I PODZIAŁU WŁADZ}

Punktem wyjścia myśli ustrojowej Rousseau w Umowie społecznej są stwierdzenia dotyczące zwierzchnictwa ${ }^{3}$. To one przesądzają o charakterze relacji łączących władzę ustawodawczą i wykonawczą, jak i o samym ujęciu władzy

\footnotetext{
2 Zob. P. Bastid, Le gouvernement d'assemblée..., s. 7 n., 13.

${ }^{3}$ Zagadnienia te omawiałem również w innych miejscach (zob. R. Lis, Jean Bodin, John Locke $i$ Jean Jacques Rousseau. O paradoksie suwerenności i ludowładztwa oraz próbach jego rozwiazania, „Studia Polityczne” 2 (2014), s. 78-83; idem, W poszukiwaniu prawdziwej rzeczypospolitej.
} 
ludu. Otóż twierdził Rousseau, zmierzając się z całą właściwe tradycją ówczesnej jurysprudencji ${ }^{4}$, że jedynym prawomocnym suwerenem jest lud, a jego prawa w tym zakresie, sprowadzone wprost do pełnej i wyłącznej władzy ustawodawczej, nie podlegają odstąpieniu i przedawnieniu ${ }^{5}$. Oznaczało to, iż nie tylko lud nie może się podporządkować bezpowrotnie żadnej władzy (wbrew Hobbesowi i Grocjuszowi) ${ }^{6}$, ale również to, że wszelkie bez wyjątku prawa i ustawy wymagały dla swej ważności zgody ludu. To właśnie z tych pozycji podkreślał Rousseau, bodaj najsilniej w dziejach myśli politycznej ${ }^{7}$, potrzebę odróżnienia władzy ustawodawczej od wykonawczej, odpowiadających dwóm odrębnym i odmienne uzasadnionym funkcjom ciała politycznego: jego „woli” i jego „sile”. Oto doszukując się istoty praw suwerennych w całości w tej pierwszej, przesądzał autor Umowy społecznej o wtórności i, jednak, podrzędności tej drugiej, jakkolwiek ściśle wyodrębnionej od pierwszej. To bowiem pierwsza z tych władz, nazywana „wolą powszechną", nadawała temuż ciału spoistości moralnej, pozostawiając drugą z władz, obciążoną zadaniem jej wykonania, w pozycji względem niej służebnej. Zastrzegał wszak Rousseau wymownie, że „taka jest w państwie racja istnienia rządu, utożsamianego niesłusznie ze zwierzchnikiem, którego rząd jest jedynie sługą"9 [podkr. - R.L.]. Wynikało stąd w szczególności, iż należne ze strony ludu podporządkowanie się temuż rządowi nie oznacza w żadnym razie utraty praw suwerennych, skoro jest to jedynie o ,zalecenie, funkcja, pełniąc którą naczelnicy, jako zwykli urzędnicy zwierzchnika, wykonują w jego imieniu władzę, którą w ich ręce złożył i którą może ograniczyć, zmienić, cofnąć, kiedy mu się spodoba, ponieważ odstąpienie takiego prawa nie da się pogodzić z naturą ciała politycznego i sprzeciwia się celom zrzeszenia"10.

Trudno doprawdy przecenić znaczenie tych rozstrzygnięć. Nie można ich zwłaszcza tracić z oczu, kiedy rozważa się dalsze ustalenia autora Umowy w przedmiocie podziału władz. Otóż kolejnym ważnym punktem Roussow-

Główne nurty myśli politycznej Sejmu Czteroletniego, Kraków 2015, s. 58-80; idem, Jean-Jacques Rousseau i James Madison. Dwa modele obywatelstwa w tradycji doktryny suwerenności ludu, „Horyzonty Polityki” 7 (2016), s. 73-90).

${ }^{4}$ Zob. zwłaszcza H. Rosenblatt, Rousseau and Geneva. From the First Discourse to the Social Contract, 1749-1762, Cambridge 1997, s. 99-101, 243 n.

${ }^{5}$ Zob. J.J. Rousseau, Umowa spoteczna, thum. A. Peretiakowicz, [w:] J.J. Rousseau, Umowa społeczna, Uwagi o rządzie polskim [...], Warszawa 1966, szczególnie s. 32 n., 39-40, 45-47, 66 n. Por. J.J. Rousseau, Ekonomia polityczna, [w:] idem, Trzy rozprawy z filozofii społecznej, thum. H. Elzenberg, Warszawa 1956, s. 288-289, 293 n.

${ }^{6}$ Zob. J.J. Rousseau, Umowa spoleczna..., s. 14-16.

7 Zob. np. M.J.C. Vile, Constitutionalism and the Separation of Powers, Indianapolis 1998 [pierwsze wydanie: Oxford 1967], s. 195 n., 218.

8 J.J. Rousseau, Umowa społeczna ..., s. 67.

${ }^{9}$ Ibidem, s. 68.

${ }^{10}$ Ibidem, s. 69. 
skiej koncepcji suwerenności ludu było twierdzenie, iż o ile zwierzchniej władzy ustawodawczej nie można dzielić i odstępować (skoro nie można tego czynić w stosunku do woli powszechnej), o tyle sama władza wykonawcza może i powinna być reprezentowana. Istotnie, twierdził Rousseau, że lud nie nadaje się do pełnienia tej roli, odwołując czytelnika do opłakanych skutków pomieszania obu władz $\mathrm{w}$ ustroju ateńskim. Z tych przecież powodów odradzał autor Umowy demokratyczną formę rządu (pojętą w sposób najściślejszy i właściwy dla epoki), opowiadając się najbardziej za rodzajem arystokracji elekcyjnej ${ }^{11}$. Zamiast jednak odczytywać podobne zastrzeżenia w kategoriach braku zaufania Rousseau do gminowładztwa czy, szerzej, kompetencji politycznych ludu jako takiego ${ }^{12}$, należałoby wiązać je ściśle z troską tego filozofa o - właśnie - samą czytelność i skuteczność zasady zwierzchnictwa. Głównym przecież powodem oddalenia ludu od bezpośredniego sprawowania funkcji wykonawczych był szczególny charakter tejże gałęzi władzy, mającej stosować szczegółowe, partykularne zarządzenia dotyczące bezpośrednio poszczególnych obywateli, wyprowadzając je w każdym przypadku z postanowień ogólnych, zawartych w ustawach. Innymi słowy, obdarzenie ludu stanowiskami urzędniczymi (wykonawczymi) prowadziłoby nieuchronnie do utracenia przez zwierzchnika „celów ogólnych” i „,wpływu interesów prywatnych na sprawy publiczne", czyli - do pomieszania, a nawet przekształcenia woli powszechnej w wolę prywatną ${ }^{13}$.

Wynika z tego jasno, że przestrzegając przed połączeniem w rękach ludu przynależnej mu władzy ustawodawczej z władzą wykonawczą, pragnął Rousseau uchronić tę pierwszą przed niszczącymi ją tendencjami partykularnymi. Pamiętać przy tym należy, że zastrzeżenia te nie zmieniały w jakimkolwiek stopniu podstawowego założenia doktryny Rousseau: to lud pozostawał wyłącznym ustawodawcą, zaś urzędnicy - jedynie jego pomocnikami, odpowiedzialnymi za zlecone przez tegoż ustawodawcę wykonanie praw. Choć realizacja tego - jak można to określać - „zlecenia” pozostawała całkowicie w gestii ,zleceniobiorcy”, to podlegał on w tym względzie pełnej i wiążącej kontroli „zleceniodawcy”. Nawet jeśli ujęcie Rousseau wskazywało na potrzebę ścisłego podziału władz, to,

11 Zob. ibidem, s. 80-83. Moment ten uwypuklał m.in. B. Manin (idem, The Principles of Representative Government, Cambridge 2002 [pierwsze wydanie: 1997], s. 74 n.).

${ }_{12}$ Zob. np. R. Fralin, Roussau and Representation: A Study of the Development of his Concept of Political Institutions, New York 1978, s. 3 n.

${ }^{13}$ Zob. J.J. Rousseau, Umowa spoleczna..., s. 68, 70, 80. Pisał zwłaszcza Rousseau, iż „nie jest dobrze, aby ten, kto wydaje ustawy, wykonywał je i aby cały lud odwracał swą uwagę od celów ogólnych, pochłonięty celami partykularnymi. Nie ma nic niebezpieczniejszego od wpływów interesów prywatnych na sprawy publiczne i nadużycie ustaw przez rząd jest mniejszym złem niż korupcja ustawodawcy" (ibidem, s. 80). 
trzymając się zasadniczego założenia o zwierzchniej władzy ustawodawczej ludu, w żadnym razie nie pozwalało na uzasadnienie równowagi ustrojowej (i właściwie pojętego ustroju mieszanego $)^{14}$.

\section{IMPLIKACJE USTROJOWE DOKTRYNY ZWIERZCHNICTWA LUDU-USTAWODAWCY I SENS KRYTYKI INSTYTUCJI PRZEDSTAWICIELSTWA}

Przyznajmy, iż Rousseau nie chciał przedstawiać wszystkich szczegółów ustrojowych, uzależniając je właściwie od czynników zewnętrznych. Nie oznacza to jednak, ż relatywizował te kwestie czy też uznawał je za drugorzędne. Owszem, nie proponował jednego wzorca ustrojowego, twierdząc początkowo, że każdy rząd ${ }^{15}$ będzie trzeba uznać za prawowity $\mathrm{i}$ - w tym sensie - republikański, o ile panują w nim ustawy, czyli, jak trzeba wnioskować, wola powszechna ${ }^{16}$. Jednak z dalszych jego ustaleń, częściowo już przytoczonych, wynika dobitnie, że największym szacunkiem darzył formę elekcyjno-arystokratyczną, która cechowała się „ograniczoną liczbą” obieralnych - przez lud z konieczności - urzędników ${ }^{17}$.

${ }^{14}$ Mam tu na myśli najbardziej rozpowszechnioną tradycję ustroju mieszanego, podnoszącą potrzebę ograniczenia i pohamowania czynnika ludowego czy też, w szerokim znaczeniu, demokratycznego. W owym czasie najlepiej wyrażali ją, prócz autorów angielskich, Monteskiusz i Jean-Louis de Lolme, wiążący ją zresztą (choćby w sposób niepozbawiony kontrowersji) z teorią podziału władz (zob. np. W.B. Gwyn, The Meaning of the Separation of Powers: An Analysis of the Doctrine from its Origin to the Adoption of the United States Constitution, New Orlean-The Hague 1965, s. 110-113, 115-116).

15 Powtórzę, iż o klasyfikacji ustroju decydowała z konieczności konstrukcja władzy wykonawczej (choćby szerzej pojętej), skoro jedynym dysponentem władzy ustawodawczej powinien być lud (zob. M.J.C. Vile, Constitutionalism and the Separation of Powers..., s. 197).

${ }^{16}$ Zob. J.J. Rousseau, Umowa społeczna ..., s. 47.

17 Ze znanych nam już względów odradzał Rousseau ściśle pojętą demokrację. Choć gotów był wyobrazić sobie republikańską monarchię, to z dalszego, niezwykle krytycznego opisu ustroju monarchicznego wynika jednoznacznie, że nie mógł go polecać, przestrzegając także przed zasadą dziedzictwa tronu. Powiedziano już, że cenił wysoko elekcyjną formę arystokracji, jednak - dodajmy - za najgorszy typ ustroju uważał w tym dziele arystokrację dziedziczną (zob. ibidem, s. 79-92). Warto też przypomnieć, że choć wyżej cenił rząd prosty od mieszanego, to w pewnych warunkach gotów był polecić także ten ostatni - tzn. wówczas, gdy zachodziła potrzeba podzielenia nadmiernie rozwiniętej władzy wykonawczej. To właśnie w tym świetle należy rozpatrywać pochwałę równowagi władz w monarchii angielskiej, przecież zasadniczo w Umowie społecznej skrytykowanej. W tym ostatnim względzie trudno się zwłaszcza zgodzić ze zbyt rozszerzającą interpretacją Alfreda Cobbana, czyniącego w tym aspekcie z Rousseau nieomal kontynuatora Monteskiusza (zob. idem, Rousseau and Modern State, London 1934, s. 103). Odmienną interpretację przedstawiał w tym ostatnim względzie W.B. Gwyn, niemniej on także znajdował w myśli Rousseau niejakie zrozumienie dla idei równowagi i ustroju mieszanego (zob. idem, The Meaning of the Separation of Powers..., s. 114). 
Lecz nawet podobne wyznanie nie przesądza możliwości aplikacyjnych rozwijanej w dziele doktryny zwierzchnictwa ludu. Za najbardziej znaczące należałoby bowiem uznać w tym względzie uwagi przedstawiane w dalszych rozdziałach trzeciej księgi Umowy, dotyczące w szczególności przedstawicielstwa i środków obrony przed nadużyciami egzekutywy.

Zacznijmy od tych ostatnich. Otóż wynikało z nich jednoznacznie, że właściwym ośrodkiem władzy politycznej powinny być stałe, periodyczne zgromadzenia ludowe, na których lud odpowiadałby w formie plebiscytu na dwa pytania: „czy życzy sobie zachować obecną formę rządu?” oraz czy chce „pozostawiać zarząd spraw tym, którzy go obecnie sprawują?" ${ }^{18}$. Potwierdzał zatem Rousseau, że rola ludu nie sprowadzała się wyłącznie do wyrażenia pierwotnej zgody na zawarcie umowy społecznej, zawsze zresztą odwoływalnej. Autor Umowy czynił bowiem z ludu aktywny, stale zwoływany, dysponujący pełnymi uprawnieniami kontroli rządu, podmiot władzy zwierzchniej ${ }^{19}$. Mógł on w założeniu w każdej chwili zmienić konstytucję, ale też odwołać i wymienić swych urzędników. Bo też - jak pisał we wcześniejszym miejscu - „z chwilą gdy lud legalnie zgromadził się jako ciało zwierzchnicze, ustaje wszelka jurysdykcja rządu, władza wykonawcza ulega zawieszeniu [...]"20. Sądzę, że to właśnie tego rodzaju ustalenia najlepiej oddawały sens wyodrębnienia władzy wykonawczej - zasady, która musiała być podporządkowana logice suwerenności ludu-ustawodawcy. Zresztą już na początku tych rozważań podawał Rousseau dalsze powody ściślejszego nadzoru nad egzekutywą. Oto przypisywał jej tendencję do nieustannego rozrostu swej władzy kosztem ludu, bo, jak pisał, „podobnie jak wola partykularna działa bez ustanku przeciw woli powszechnej, tak rząd ciągle występuje przeciw zwierzchnictwu"21. W następstwie tych wysiłków musiało więc „prędzej czy później” dojść do złamania umowy społecznej przez rząd i przejęcia władzy suwerennej ludu. To właśnie te okoliczności unaoczniały potrzebę możliwie najbardziej skrupulatnej kontroli władzy wykonawczej przez zgromadzony lud. Wnioskował stąd Rousseau, że „im więcej rząd ma siły, tym częściej powinien się ukazywać zwierzchnik"22.

Jednak najbardziej elementarnym następstwem zastosowania logiki zwierzchnictwa ludu-ustawodawcy, domagającej się oddania pełni uprawnień ustawodaw-

18 J.J. Rousseau, Umowa społeczna..., s. 121.

19 Zob. zwłaszcza E. Putterman, Rousseau, Law and the Sovereignty of the People, Cambridge 2010, s. 28-29, 74, 107.

20 J.J. Rousseau, Umowa społeczna ..., s. 110.

${ }^{21}$ Ibidem, s. 102.

${ }^{22}$ Ibidem, s. 109. Propozycja ta zdawała się podpowiadać, że wyrażone już w Ekonomii politycznej zapewnienia, iż nie trzeba zwoływać „całego narodu” „przy każdym zdarzeniu nieprzewidzianym" (idem, Ekonomia polityczna ..., s. 298; zob. E. Putterman, Rousseau ..., s. 152-153), można była jedynie odnieść do warunków idealnych. 
czych ludowi, musiała być instytucja bezpośredniego uchwalania ustaw przez podobne zgromadzenia. Choć Rousseau wspomniał o niej wprost tylko zdawkowo (już w kolejnej księdze, w rozdziale poświęconym głosowaniom) ${ }^{23}$, to wynika ona w całości z ogólnej wizji władzy zwierzchniej. Jakkolwiek należy mieć zawsze w pamięci bardziej filozoficzne ostrzeżenia autora Umowy przed prostym utożsamieniem woli powszechnej z wolą większości czy nawet ogółu ${ }^{24}$, to bynajmniej nie wolno z tego wynosić, iż lud jako taki nie powinien się gromadzić zbyt często.

Owszem, nie brakuje w twórczości Rousseau dowodów niepokoju o rozpoznanie woli powszechnej przez zepsuty czy nieoświecony politycznie ogół obywateli ${ }^{25}$. Jednak zasadniczy wywód Umowy nie pozostawia większych wątpliwości co do zasadniczego kierunku myśli Rousseau, oferującej bodaj najsilniejsze w owym czasie, najbardziej subtelne uzasadnienie rzeczywistego, bezpośredniego zwierzchnictwa ludu ${ }^{26}$. Najlepiej zdaje się ją ujawniać zapowiedziany już rozdział o „posłach, czyli przedstawicielach”. Otóż Rousseau jednoznacznie potępił ideę przedstawicielstwa, przypominając, iż woli powszechnej reprezentować nie można: ,jest taka właśnie lub inna, nie ma tu nic pośredniego" "27. Władzę ustawodawczą powinien zatem lud realizować osobiście, a „wszelka ustawa, której lud nie uznał, jest nieważna; nie jest wcale ustawą" ${ }^{28}$. To właśnie te ustalenia doprowadziły Rousseau do słynnego potępienia ustroju angielskiego, gwarantującego - jak stwierdzał - tamtejszemu ludowi jedynie pozorną wolność - skoro bowiem Anglicy obrali już członków parlamentu, stawali się rychło „niewolnikami”.

Tak kategoryczna krytyka miała oczywiście znacznie szerszy wymiar, ukazując w pełni sens Roussowskiego republikanizmu. Rousseau potępiał instytucje przedstawicielstwa, bo wiązał je z osłabieniem ducha patriotycznego i wartościami nowoczesnego społeczeństwa handlowego ${ }^{29}$. Niezdolni do poświęceń publicz-

${ }^{23}$ Dokładniej mówiąc, pisał Rousseau, iż ,gdy proponuje się ustawę na zgromadzeniu ludowym, obecni są pytani nie o to właściwie, czy pochwalają lub odrzucają wniosek, ale tylko, czy jest on zgodny, czy niezgodny z wolą powszechną, która jest ich wolą; każdy oddając głos wyraża swoje zdanie w tej sprawie i z obrachunku głosów wynika deklaracją woli powszechnej” (J.J. Rousseau, Umowa społeczna..., s. 127).

${ }^{24}$ Znamienne zresztą, że w miejscu, w którym wyjawiał Rousseau potrzebę zatwierdzania ustaw przez zgromadzenia ludowe, przywoływanym w przypisie powyżej, dodawał Rousseau, że podporządkowanie się wynikowi głosowania wedle reguły większości, będącej w podobnym przypadku najlepszym sposobem deklarowania woli powszechnej, zakłada się, iż „,wszystkie cechy woli powszechnej znajdują się jeszcze u większości; gdy straci je, bez względu na to, co się postanawia, nie ma już wolności" (ibidem, s. 127).

${ }^{25}$ Zob. ibidem, s. 36, 47, 70, 81, 83, 116. Jednak por. ibidem, s. 112-113.

${ }_{26}$ Zob. zwłaszcza J. Miller, Rousseau: Dreamer of Democracy, New Haven-London 1984, s. 120; E. Putterman, Rousseau ..., s. 9; H. Rosenblatt, Rousseau and Geneva ..., s. 245.

27 J.J. Rousseau, Umowa spoleczna..., s. 113.

${ }^{28}$ Ibidem.

${ }^{29}$ Zob. ibidem, s. $111 \mathrm{n}$. 
nych, zniewieściali, oddani prywatnym sprawom obywatele przestawali doceniać potrzebę osobistych obrad publicznych i obrony, przekazując te zadania przedstawicielom i żołnierzom. Jednak tym sposobem przestawali być zdolni do rozpoznawania i wyrażania samej woli powszechnej, będącej istotą samego ciała politycznego, zasługując w pełni na polityczną niewolę. Abstrahując jednak od tych ważnych aspektów myśli Rousseau, powtórzmy, że najważniejszy zarzut wynikał $\mathrm{z}$ niezgody tego filozofa na przekazanie uprawnień zwierzchnich (ustawodawczych) obieralnym choćby urzędnikom, utożsamiane z konieczności z uzurpacją i pogwałceniem dyktatów woli powszechnej. By temu zapobiec, musiał więc lud nieustannie być zwoływany na zgromadzenia, których głównym zadaniem pozostawałoby uchwalanie ustaw. Trudno nie doszukiwać się w tym miejscu pełnej akceptacji instytucji bezpośrednich rządów obywatelskich.

Ostatecznie oznaką najlepiej urządzonego państwa było to, że każdy w nim „spieszy na zgromadzenia obywatelskie" ${ }^{30}$. Znaczenie tych zapewnień trzeba tym bardziej docenić, że Rousseau zdawał sobie doskonale sprawę z zarzutów stawianych pod adresem podobnych instytucji („Lud zgromadzony, powie ktoś, co za mrzonka!”), a jednak tym bardziej na nie nalegał („Dzisiaj jest to mrzonką, ale nie było przed dwoma tysiącami lat. Czyżby zmieniła się natura ludzka?"31). Lecz mimo to omawiane tu zagadnienie mogło okazać się bardziej skomplikowane, skoro w najważniejszym miejscu przywoływanej tu krytyki przedstawicielstwa dopowiadał Rousseau, że ,posłowie ludu nie są więc i nie mogą być jego przedstawicielami, są jedynie ajentami i nie mogą nic rozstrzygnąć ostatecznie"32. Czyżby więc nie zamykał całkowicie autor Umowy drogi przed jakimś uzasadnieniem instytucji poselstwa, od przedstawicielstwa odróżnionego? Z pewnością. Reguła ta musiała jednak być uzgodniona z nadrzędną zasadą, głoszącą, iż zasadniczo żadna ustawa nie mogła być ważna i wiążąca, o ile nie cały lud nie wyraził na niej swej zgody.

\section{KOMPROMISY USTROJOWE W UWAGACH O RZĄDZIE POLSKIM?}

Trudno się nie zgodzić z Alfredem Cobbanem, że uwagi Rousseau, zatroskanego najbardziej losem ojczystej Genewy, mają przede wszystkim zastosowanie do państw małych rozmiarów ${ }^{33}$. Nie należy jednak przez to sądzić, że reprezentowany przez niego typ konstytucjonalizmu nie przedstawia szerszych możliwości aplikacji. Owszem, ideałem ustrojowym Rousseau są bezpośrednie rządy zgroma-

\footnotetext{
30 Ibidem, s. 112.

31 Ibidem, s. 107.

32 Ibidem, s. 113.

33 Zob. A. Cobban, Rousseau and Modern State..., s. 108.
} 
dzenia obywateli, zwoływanego cyklicznie celem zarówno ratyfikacji ustaw, jak i kontroli urzędników rządowych, odpowiedzialnych głównie za wykonywanie ustaw $^{34}$. Niemniej rozleglejszy kontekst myśli ustrojowej, wskazujący na szersze rozumienie ustroju prawowitego (republikańskiego), jak i komentowane właśnie wyjątki dotyczące posłów (jako „ajentów” a nie przedstawicieli), podpowiadają wyraźnie, że Rousseau nie przekreślał z definicji możliwości wprowadzenia wolnego ustroju w większych państwach, choćby nawet ujawnił w tym względzie więcej pesymizmu ${ }^{35}$.

Najlepszych dowodów gotowości wieloaspektowego spojrzenia Rousseau dostarczają Uwagi o rządzie polskim. Treść dzieła ukazuje przede wszystkim, że dzięki wprowadzeniu formuły federacyjnej, a zarazem wzmocnieniu czynnika władzy, państwo dużych rozmiarów mogło z powodzeniem realizować republikańską formę rządu. Choć ówczesna Polska, utrzymująca przeważającą większość swych mieszkańców w stanie poddaństwa osobistego, nie mogła być oceniona przez Rousseau w całości pozytywnie, to charakterystyczne dla jej tradycji instytucje szlacheckiej demokracji mógł on uznać za niezwykle obiecujące. Można wręcz twierdzić, że uwagi dotyczące tych instytucji uzupełniały znacząco oblicze Roussowskiego konstytucjonalizmu. Przede wszystkim rozwiązywały uwydatniony tak dobitnie w Umowie społecznej paradoks suwerenności i przedstawicielstwa ${ }^{36}$. Dzieło to potwierdzało ujawnioną w Umowie wizję służebnej roli urzędników państwowych, przestrzegając przed grożącym zawsze $\mathrm{z}$ ich strony przejęciem praw zwierzchnich,

${ }^{34}$ Warto dodać, że w ujęciu Rousseau rząd był odpowiedzialny także za przygotowanie projektów ustaw, przedkładanych następnie ludowi do ratyfikacji (zob. idem, Rozprawa o pochodzeniu i podstawach nierówności między ludźmi, [w:] idem, Trzy rozprawy z filozofii społecznej..., 115 n.). Jak jednak wykazał Ethan Putterman, koncepcja ta w niczym nie nadwyrężała suwerennych praw ludu, dysponującego nie tylko wyłącznymi uprawnieniami uchwalania ustaw, ale także pełnymi możliwościami odwołania źle ocenionego rządu (zob. idem, Rousseau ..., s. 46 n.). Przypomnijmy, że choć ten ostatni miał realizować przynależne funkcje wykonawcze w sposób autonomiczny i niezależny (zob. np. A. Cobban, Rousseau and Modern State..., s. 106), to ostateczne podlegał pełnemu nadzorowi zwierzchnika. Lud nie tracił bowiem nigdy praw zmiany rządu, choćby w tym jednym przypadku decyzja w tym zakresie miała charakter aktu szczególnego, uzasadnionego jednak samą genezą stowarzyszenia (zob. J.J. Rousseau, Umowa społeczna ..., s. 115 n.).

${ }^{35}$ Ogólnie biorąc, Rousseau podzielał typowe już dla tych czasów, spopularyzowane przez Monteskiusza przekonanie, że ustrój republikański można z powodzeniem zastosować w małych, homogenicznych państwach. Jednak za tym stwierdzeniem stały u Rousseau względy bardziej teoretyczne: wraz bowiem ze wzrostem państwa musiała wzrastać siła rządu w stosunku do ludu jako poddanych, jednak wzrost potęgi rządu powodował jednocześnie potrzebę zwiększenia wpływu ludu jako zwierzchnika (zob. ibidem, s. 70-78, 109). Jak można było stąd wnioskować, największą trudnością stojącą przed wielkimi republikami była konieczność znacznie bardziej częstotliwego zwoływania suwerena, technicznie przecież wręcz niemożliwego do przeprowadzenia.

${ }_{36}$ Zob. zwłaszcza K.M. Baker, Representation, [w:] The French Revolution and the Creation of Modern Political Culture, t. 1: The Political Culture of the Old Regime, red. K.M. Baker, Oxford 1987, s. 479. 
przysługujących jedynie narodowi (jakkolwiek pojętemu). W tym względzie przynosiło ono niezmiernie ważne rozstrzygnięcia interesujących nas zagadnień demokracji bezpośredniej i tzw. rządów zgromadzenia.

Zacznijmy od tego, że w najważniejszym miejscu swych rozważań wyraził Rousseau zdumienie, iż władza ustawodawcza nie uległa jeszcze pod naporem władzy wykonawczej ${ }^{37}$. Nie doszło do tego, po pierwsze, z powodu ,ustawicznej obecności prawodawcy" oraz, po drugie, dzięki podziałowi i częstym zmianom władzy wykonawczej. Jeśli częste sejmy i rotacje posłów uniemożliwiły dworowi przekupienie posłów, to zmiany i podziały w obrębie egzekutywy (zwłaszcza ministrów) „udaremniły jej depozytariuszom wspólne działanie dla uciśnienia legislatywy"38. Znamienne, że odwołując czytelnika do komentowanych już tu fragmentów Umowy społecznej, powtarzał wkrótce Rousseau, iż „każde ciało będące depozytariuszem władzy wykonawczej dąży usilnie i wytrwale do ujarzmienia władzy prawodawczej i osiąga to wcześniej czy później" ${ }^{39}$. Uwagi potwierdzały więc, a nawet uczytelniały wcześniejszą ocenę Rousseau, rzutując w całości na obraz egzekutywy - koniecznej w każdym państwie gałęzi władzy, lecz wykazującej stałą, „naturalną” tendencję do uzurpacji. Już z treści Umowy wynikało jednoznacznie, iż jeśli w dużym państwie potrzeba tej władzy rosła, to w równej mierze wzrastała także potrzeba jej nadzorowania. Nic tak dobrze nie oddaje tej myśli, jak twierdzenie autora Uwag, iż ,aby administracja była silna, dobra i spełniała należycie swe zadania, cała władza wykonawcza powinna spoczywać w jednych rekach; nie wystarcza jednak, żeby te ręce się zmieniały, muszą także działać, w miarę możliwości, tylko pod kontrolą ustawodawcy i ustawodawca musi nimi kierować" ${ }^{40}$.

Jak widać, Uwagi podkreślają jeszcze wyraźniej konieczność kontrolowania władzy wykonawczej przez ustawodawcę, jakkolwiek od niego wyodrębnionej. Podpowiadają one, że postulowanego tak zdecydowanie w Umowie społecznej podziału władz nie można opisywać w kategoriach ich równowagi. Jeśli nawet Rousseau gotów był osłabić nieznacznie wyrazistość tego podziału, komentując specyficznie polskie tradycje instytucjonalne (uwzględniające zarówno role ustrojowe elekcyjnego króla, ministrów, jak i senatu, który pośredniczył między królem a izbą poselską), odtwarzane wprawdzie w schemacie zasadniczego zwierzchnictwa szlacheckiego narodu ${ }^{41}$, to ogólny kierunek jego zaleceń nie podlega wąt-

${ }^{37}$ Zob. J.J. Rousseau, Uwagi o rządzie polskim, thum. M. Staszewski, [w:] J.J. Rousseau, Umowa spoleczna oraz Uwagi o rzadzie polskim..., s. $213 \mathrm{n}$.

${ }^{38}$ Ibidem, s. 213.

${ }^{39}$ Ibidem, s. 215.

${ }^{40}$ Ibidem, s. 216-217.

${ }^{41}$ Przyznać trzeba, że Uwagi nie przedstawiają całkowicie spójnej i czytelnej koncepcji władzy wykonawczej. Umieszczał ją zasadniczo pomiędzy królem, odpowiedzialnym wprawdzie bardziej 
pliwości. Niezależnie od tego, jaki kształt ustrojowy miałaby przybrać władza wykonawcza, która powinna być - optymalnie - zarówno skupiona, jak i mniej lub bardziej podzielona wewnętrznie czy wręcz kolegialna, musiała ona zostać oddalona, możliwie najbardziej, od prawodawstwa i pozostawać - powtórzę pod ogólnym nadzorem zwierzchnika ${ }^{42}$. To zresztą w tym ostatnim względzie Uwagi przynosiły najbardziej decydujące dla konstytucjonalizmu Rousseau rozstrzygnięcia. Przypomnieć tu trzeba, że jednym z powodów, dla których władza ustawodawcza nie uległa w Polsce przejęciu przez egzekutywę, była stała „obecność" ustawodawcy. Rousseau miał tu na myśli nie tylko wspomnianą częstotliwość obrad sejmowych i zmian w składzie sejmu. Wkrótce bowiem wyjaśniał, że prawdziwym ,palladium wolności” były w Polsce sejmiki, będące faktycznie rodzajem bezpośrednich zgromadzeń obywatelskich na poziomie lokalnym.

Trudno doprawdy przecenić znaczenie tego punktu. Jak pamiętamy, w Umowie Rousseau poddał druzgocącej krytyce instytucję przedstawicielstwa, nie pozostawiając właściwie jakichkolwiek możliwości jej uzasadnienia - wyjąwszy wprawdzie zastrzeżenie, że posłowie, najwyraźniej odróżnieni od przedstawicieli w ścisłym znaczeniu, nie powinni być niczym więcej niż „ajentami” ludu (o ile w ogóle byli konieczni). Wątku tego Rousseau nie rozwinął w swym najważniejszym dziele, czy to z powodu braku godnych polecenia przykładów podobnych rozwiązań, czy też z uwagi na główne zainteresowanie instytucjami bezpośrednimi. Jednak przygotowując Uwagi, mógł się już zapoznać z polskimi ideałami sejmikowania i, przede wszystkim, instruowania posłów przez sejmiki ${ }^{43}$. Niewątpliwie rozwiązania te, jakkolwiek oczywiste dla polskich czytelników, pozwalały rozstrzygnąć jeden z największych dylematów teoretycznych Roussowskiego konstytucjonalizmu. Pozwalały mianowicie uzgodnić regułę zwierzchnictwa narodu z warunkami dużego państwa, które nie przedstawiało możliwości bezpośredniego zgromadzenia wszystkich obywateli. Oto dzięki wiążącym instrukcjom, układanym bezpośrednio przez obywateli, posłowie pozostawali jedynie zleceniobiorcami narodu, on zaś sam nie tracił naczelnej władzy zwierzchniej. Jak bowiem wyjaśniał Rousseau, ,przy każdym słowie wypowiadanym w sejmie,

za nadzór nad urzędnikami, a senatem, tyleż „wyposażonym we władzę wykonawczą”, ileż pośredniczącym „między izbą posłów a królem”. Znamienne w każdym razie, że ministrowie (w tym hetmani wielcy i podskarbi wielcy), najbardziej odpowiedzialni za „szczegóły administracji”, wybierani przez sejm, mieli zasiadać w senacie. Sam senat miał być złożony z członków dożywotnich, tj. wybieranym przez króla (lub kapituły) biskupów oraz wybieranych - najlepiej - przez sejmiki wojewodów i tzw. kasztelanów większych (dołączał jeszcze do tego ciała Rousseau właściwie także ministrów) oraz dokooptowanych do tego grona senatorów-posłów, czyli tzw. kasztelanów mniejszych, wybieranych co dwa lata przez sejm. Zob. ibidem, s. 227-230, 233.

${ }^{42}$ Zob. ibidem, s. 216-217.

${ }^{43} \mathrm{Na}$ temat kontekstu powstania Uwag o rzadzie polskim i znaczenia pośrednictwa Michała Wielhorskiego zob. J. Michalski, Rousseau i sarmacki republikanizm, Warszawa 1977. 
przy każdym swoim kroku, poseł musi już widzieć się zawczasu w obliczu swych mocodawców i czuć wpływ, jaki ich sąd wywrze zarówno na jego projektach dalszej kariery, jak i na szacunku dlań ze strony rodaków; bo przecie naród wysyła posłów na sejm nie po ty, aby tam wygłaszali swoje osobiste poglądy, lecz aby wypowiadali wolę narodu. Takie wędzidło jest bezwzględnie konieczne, aby utrzymać posłów w granicach obowiązków i zapobiec wszelkiej skądkolwiek pochodzącej korupcji”"44.

Zgromadzenia obywatelskie zachowywały więc pośrednio zasadniczy wpływ na kształt ustaw. Lecz mimo to dochodziło tym sposobem do przeniesienia ciężaru sprawowania władzy ustawodawczej na posłów reprezentujących - w opisanym tu znaczeniu - cały naród. Znamienne, że ustawy uchwalane przez sejm musiały już obowiązywać obywateli, którzy nie mogli zasadniczo sprzeciwiać się decyzjom sejmu - w przeciwnym razie powstałyby niedające się rozwiązać spory kompetencyjne między sejmem a sejmikami. Wprawdzie przyznawał Rousseau sejmikom prawo surowego ukarania posłów na sejmikach relacyjnych i, oczywiście, prawo wniesienia dowolnych zastrzeżeń w instrukcjach na przyszły sejm, niemniej decyzja sejmu musiała być wiążąca. W pewnym więc sensie to sejm wyobrażał zwierzchnictwo narodu, choć jego zasadniczym, pierwotnym źródłem była wola tego ostatniego, wyrażona na poszczególnych sejmikach i wiążąca we wszystkich przypadkach posłów. Jeśli ci ostatni poza nią wykraczali podczas głosowań nad poszczególnymi projektami, sprzeniewierzali tym samym pokładane w nich, zawsze warunkowe zaufanie. Niemniej ważne względy systemowe wymagały, by uznać, zasadniczo, sam wynik głosowania za wiążący.

Podobne rozstrzygnięcia niewątpliwie ukazywały gotowość mniej pryncypialnego stanowiska w sprawie rządów bezpośrednich, zdradzając niejaką gotowość bardziej pośredniej formuły władzy ludu. Jak zauważał słusznie Robert Derathé, bardziej konsekwentne ujęcie wskazywałoby na konieczność ratyfikacji ustaw przez same sejmiki, nie zaś $\operatorname{sejm}^{45}$. W tym więc względzie można chyba mówić o ważnym przesunięciu akcentu w ujęciu filozofa ${ }^{46}$. Trudno jed-

${ }^{4}$ J.J. Rousseau, Uwagi o rządzie polskim ..., s. 219-220.

${ }^{45}$ Zob. R. Derathé, Jean-Jacues Rousseau et la science politique de son temps, Paris 1970, s. 279 .

${ }^{46}$ Być może pozwalałoby ono na wyprowadzenie koncepcji tzw. sejmu rządzącego, popularnej skądinąd pośród takich polskich pisarzy reformatorskich i republikańskich z lat Sejmu Czteroletniego, jak Stanisław Staszic i, przede wszystkim, Hugo Kołłątaj. Znamienne, że nie rezygnowali oni również z ideałów instrukcji wiążących, przestrzegając równie silnie jak Rousseau przed zbyt samodzielną władzą wykonawczą (zob. R. Lis, W poszukiwaniu prawdziwej rzeczypospolitej..., s. 155, 164 n., 203 n.). Niemniej autorzy ci domagali się znacznego wydłużenia obrad sejmu (Kołłątaj mówił wręcz w Listach anonima o „sejmie trwałym”), gdy tymczasem Rousseau przewidywał raczej tylko możliwość przedłużenia ich w trybie specjalnej ustawy (zob. J.J. Rousseau, Uwagi o rządzie polskim..., s. 221). Jednak wymienieni polscy reformatorzy najbardziej oddalali się od Rousseau 
nak wnioskować stąd, iż Rousseau uzgodnił tym samym ideę suwerenności ludu z zasadami rządu przedstawicielskiego, szczególnie w krytykowanym przezeń rozumieniu. Powtórzyć trzeba bowiem, że choć decyzje sejmu były wiążące, to były zarazem związane zasadniczo treścią instrukcji. Bądź co bądź, tenże sejm miał się kierować nie wolą posłów, lecz wolą województw, a posłowie pozostawali pod omówioną już kontrolą tych ostatnich. Choć nie wyobrażał sobie istotnie Rousseau, by województwa, a tym bardziej posłowie mogli się nie podporządkować ważnie podjętej uchwale sejmowej (przegłosowanej większością głosów, zresztą w ważniejszych kwestiach - kwalifikowaną ${ }^{47}$ ), to jednak, nie odbierał gromadzonemu oddolnie narodowi prawa protestu - i to nie tylko w przywołanej już formie zastrzeżeń w kolejnych instrukcjach. Chodzi tu w szczególności o generalne prawo narodu do konfederowania się na wypadek zagrożenia ojczyzny i wolności. Znamienne, że już we wcześniejszym miejscu Uwag uznał Rousseau konfederacje (mając na myśli w szczególności współczesne wystąpienie konfederatów barskich) za równie istotne jak sejmiki gwarancje zachowania ustroju Polski: „co do mnie, jestem przekonany, że jeśli konfederacja uratowała ojczyznę, to sejmiki ją zachowały [...]"48. Dalszy wywód dzieła potwierdzał znaczenie tej instytucji w ogóle, nazwanej ,puklerzem, azylem, sanktuarium tego ustroju” i wreszcie -,,arcydziełem polityki”49. To ostatnie określenie nie było przypadkowe i mogło już zapowiadać bardziej uniwersalne treści ustrojowe. Dokładniej mówiąc, Rousseau uznał konfederację za najlepszy nadzwyczajny i ostateczny środek obrony wewnętrznej ustroju republikańskiego, przewyższający znacznie proponowaną w Umowie społecznej,

w innym punkcie, mianowicie w postulacie dziedzictwa tronu, przed którym autor Uwag bezwiednie przestrzegał (ibidem, s. 235). W tym względzie to ich przeciwnicy, tzw. szlacheccy republikanie, z Adamem Wawrzyńcem Rzewuskim na czele, uosabiali najlepiej Roussowskie ideały ustrojowe (zob. R. Lis, W poszukiwaniu prawdziwej rzeczypospolitej ..., s. 354-376).

${ }^{47}$ Odnotujmy, że Rousseau zasadniczo krytykował instytucję liberum veto, obarczając ją winą za paraliż funkcji sejmowych (zob. idem, Uwagi o rządzie polskim..., s. 217, 242-243). Jak pisał, „absurdem jest [...], żeby w jakimkolwiek wypadku jeden członek sejmu mógł wstrzymać jego czynności i żeby usunięcie się czy protest jednego lub kilku posłów mogły rozwiązywać zgromadzenie i w ten sposób unicestwiać zwierzchnią władzę" [podkr. - R.L.] (ibidem, s. 242-243). Pomijając tu okoliczność, że podobne sformułowania pozwalałby już doszukiwać się dalej nawet idącej zmiany stanowiska Rousseau (choć jednak nie należy ich wyrywać z szerszego kontekstu rozważań ustrojowych), warto zwrócić uwagę na równie wymowne wahania filozofa w przedmiocie komentowanego tu prawa, nazwanego dwa akapity dalej „,pięknym prawem”, przemawiającym najwyraźniej jeszcze do wyobraźni tegoż piewcy powszechnej woli narodu. Ostatecznie gotów był przyznać autor Uwag warunkowo to prawo pojedynczym posłom, zastrzegając, że po zerwaniu sejmu byliby oni sądzeni przez specjalny trybunał narodowy, który mógłby wydać tylko dwa rodzaje wyroków: karę śmierci lub ułaskawienia, skutkującego nagrodzeniem posła najwyższymi honorami państwowymi (zob. ibidem, s. 243-244).

${ }^{48}$ Ibidem, s. 219.

49 Ibidem, s. 245. 
znaną z dziejów Rzymu instytucję dyktatury ${ }^{50}$. Dostrzegając w konfederacji najbardziej zgodną z wolnością i konfederacyjnym charakterem Rzeczypospolitej instytucję stanu wyjątkowego, nalegał autor Uwag, by w żadnym razie jej nie likwidować. Proponował jedynie, by uregulować precyzyjnie wszystkie przypadki jej zastosowania. Istotne, że poza okolicznościami wojny czy obcej interwencji, wskazywał w tym przedmiocie Rousseau na przypadek utrudniania i ograniczania prac sejmu.

Konfederacja byłaby w tym ostatnim wypadku rzeczywistym uosobieniem władzy zwierzchniej, ukazując ostateczne oblicze suwerena w momencie, kiedy nie mógł on działać w normalnym trybie, tj. poprzez poinstruowanych przezeń posłów. Choć Rousseau nie wyraził wprost tego ujęcia, to zdaje się je potwierdzać pośrednio obraz Rzeczypospolitej przedstawiony wkrótce przez samego Michała Wielhorskiego, pośredniczącego od początku w kontaktach konfederatów ze słynnym filozofem. Znamienne, że Wielhorski wprost określał ów ustrój mianem „konfederackiego”, rozwijając znacząco myśl o „pierwiastkowej” udzielności ziem, powiatów i województw, tworzących dopiero „zupełną Rzeczypospolitej postać i powage", ujawnianej zwłaszcza w trakcie zwoływania konfederacji generalnej ${ }^{51}$. Z punktu widzenia podejmowanego tu tematu najważniejsze byłoby to, iż już w samym ujęciu Uwag o rządzie polskim konfederacja, stanowiąca najbardziej wyjątkową, ale też bezpośrednią w swej istocie formę wystąpienia ogólnonarodowego, zbliżałoby faktycznie funkcje wykonawcze do ustawodawczych, jakby wbrew zasadniczemu przesłaniu Umowy społecz$n e j$. Pisał wszak Rousseau, że ,władza wykonawcza związana z konfederacjami da im zawsze w ostatecznej potrzebie więcej energii, ruchliwości, szybkości w działaniu, niż by mógł mieć sejm, z konieczności wolniej się poruszający, zachowujący więcej formalności i nie mogący uczynić żadnego niezgodnego z porządkiem kroku bez obalenia ustroju" ${ }^{52}$.

Nie ma potrzeby nadmiernego uwypuklania komentowanego fragmentu Uwag. Przyznać jednak należy, że wraz z szeregiem innych propozycji tego dzieła, zdaje się on rzucać nowe światło na najważniejsze ustalenia Umowy. Z pewnością podobne rozważania potwierdzały, że choć przesuwał Rousseau ciężar podejmowania decyzji prawodawczych na zgromadzenie poselskie, po-

${ }^{50}$ Wyższość polskich rozwiązania polegała na tym, że „będąc jedynie środkiem wzmocnienia i przywrócenia ustroju wstrząśniętego wielkimi wysiłkami, mogą naciągnąć i wzmocnić rozluźnioną sprężynę państwa, ale nigdy nie mogą jej zerwać” - i choć „każde wolne państwo, w którym nie przewidziano wielkich kryzysów, narażone jest na śmiertelne niebezpieczeństwo”, to „tylko Polacy umieli nawet z tych kryzysów wyciągnąć nowy środek utrzymania ustroju” (ibidem, s. 245).

${ }_{51}$ Zob. Michał Wielhorski, O przywróceniu dawnego rządu wedlug pierwiastkowych Rzeczypospolitej ustaw, Warszawa 1775, szczególnie s. 42-45.

52 J.J. Rousseau, Uwagi o rzadzie polskim..., s. 246. 
zostawał zasadniczo wierny ideałom bezpośrednich, kontrolno-zatwierdzających rządów obywatelskich. Przesądzał o tym to stosunek do sejmików i konfederacji, mających stanowić fundament polskiego ustroju. Toteż zamiast o odejściu od pryncypiów demokracji bezpośredniej należałoby raczej mówić o próbie ich zaszczepienia w warunkach rozległego państwa, w których nie można było wprowadzić powszechnych zgromadzeń ustawodawczych. Rousseau przyznawał przecież narodowi bezpośrednie środki wpływu na prawodawstwo i ścisłej kontroli posłów, utwierdzając go bez wątpienia w poczuciu odpowiedzialności za wiążące go prawa. Choć z powodów technicznych nie oddawał tych praw do ratyfikacji sejmikom, to tym ostatnim nie odbierał praw rozliczenia (ukarania) posłów, związanych uprzednio ich wolą, i późniejszych protestów. Ostatecznie zaś gwarantował narodowi pełne prawa do konfederacji - także na wypadek uzurpacji funkcji ustawodawczych. Uwagi nie przynoszą więc jakiejś zasadniczej zmiany założeń konstytucjonalizmu Rousseau, niemniej przenosząc uwagę z małych państw na wielkie, ukazują nowe konteksty i, zapewne, drogi jego rozwoju. W tym względzie unaoczniają jeszcze wyraźniej niebezpieczeństwo uzurpacji ze strony władzy wykonawczej, potwierdzając potrzebę jej stałej kontroli. Wprawdzie znajdujemy w tym dziele pewne ślady gotowości odejścia od rygoryzmu zasady ścisłego podziału władz, to w żadnym razie nie wynikają one z zamiaru ich równoważenia, mającego zwłaszcza na celu pohamowanie władzy ustawodawczej sejmu. Raczej należałoby w tym dostrzegać próbę wprzęgnięcia tradycyjnych instytucji ustrojowych (króla i senatu) w strukturę republikańskiego ustroju. Ważniejsze w tym kontekście wydają się ustalenia Rousseau dotyczące stanu wyjątkowego, przedstawiającego najlepszą sposobność ukazania się rzeczywistego suwerena. To one ujawniały w pełni konfederacyjną czy też „zgromadzeniową" naturę Rzeczypospolitej, a z drugiej strony - zależny i powierniczy (czy nawet prowizoryczny) charakter samych funkcji wykonawczych, ulegających nie tylko zawieszeniu, ale wręcz przejęciu przez bezpośrednio działający naród. Owszem, te ostatnie okoliczności zdają się niebezpiecznie naruszać ideały podziału władz, tak czytelnie wyłożone w Umowie. Przede wszystkim jednak podpowiadają, że nie można ich rozwijać w oderwaniu od najbardziej zasadniczej dla Rousseau wartości ustrojowej, jaką było zwierzchnictwo narodu.

$$
* * *
$$

W świetle opisanej tu myśli Rousseau nie można przeciwstawiać z taką łatwością zasad rządów bezpośrednich i szerzej pojmowanych rządów zgromadzenia. Przeciwnie, wskazuje ona na silne powinowactwo wiązanych z nimi ideałów zwierzchnictwa narodu, nadrzędności funkcji ustawodawczych i pełnej odpowiedzialności urzędników przed narodem. $\mathrm{Z}$ dokonanego zestawienia 
treści Umowy z propozycjami Uwag można wnioskować o możliwości przeniesienia uwagi z bezpośrednich zgromadzeń ludu-obywateli na pośrednie zgromadzenia ustawodawcze. Nie oznaczało ono jednak zerwania z ideałami rządów bezpośrednich. Przesunięcie to, warunkowane potrzebami zastosowania konstytucjonalizmu republikańskiego do dużych państw, mogło w obiecujący sposób otwierać nowe perspektywy rozwoju tej doktryny, zważywszy zwłaszcza na przewagę tego rodzaju państw w ówczesnej Europie. Uwagi o rządzie polskim nie spełniły jednak tej roli i popadły szybko w zapomnienie. Owszem, myśl Rousseau wpłynęła wydatnie na treść doświadczeń ustrojowych rewolucyjnej Francji, jednak przeważyło tam ostatecznie bardzo nowatorskie odczytanie konceptu „woli powszechnej”, wykraczające nie tylko poza wytyczne mniej znanych francuskiej publiczności Uwag, ale i lekceważące najważniejsze przestrogi samej Umowy. Pod niewątpliwym wpływem Emmanuela Sieyèsa sprowadzono tę wolę do woli abstrakcyjnie pojętego narodu, reprezentowanego koniecznie przez wolnych od instrukcji przedstawicieli ${ }^{53}$. Paradoksalne, że najbardziej wpływowe nurty rewolucyjnego, inspirowanego przez Rousseau republikanizmu, podtrzymujące w każdym razie ideały suwerenności narodu i, jednocześnie, podziału władz ${ }^{54}$, nie rozwinęły zasadniczo ideałów bezpośrednich rządów obywatelskich. Wydaje się, że łatwo z tej perspektywy zrozumieć, że kiedy późniejsze doświadczenia skłoniły konstytucjonalistów Rewolucji do odrzucenia rygoryzmu mocniej rozumianej zasady podziału władz i przejęcia pełnej władzy przez Konwent Narodowy ${ }^{55}$, reguły rządów zgromadzenia, rozumianych już literalnie, oraz rządów bezpośrednich mogły uchodzić za całkowicie opozycyjne. Choć myśl Rousseau istotnie otwierała drogę szerzej rozumianemu sejmowładztwu, to, nie rezygnując zwłaszcza z imperatywu bezpośredniej kontroli posłów przez lokalne zgromadzenia obywatelskie, nie oddalała się od modelu bezpośrednich rządów obywatelskich. Można w związku tym przypuszczać, że dopiero powiązanie reguły rządów zgromadzenia z zasadami przedstawicielstwa i wolnego mandatu, dokonane już wbrew intencjom Rousseau, pozwalało umieścić tę pierwszą zasadę w opozycji do ideałów demokracji bezpośredniej.

${ }^{53} \mathrm{Na}$ temat koncepcji Sieyèsa zob. K.M. Barker, Representation, op.cit., s. 487-489. Na temat podobnych tendencji w obrębie tradycji angloamerykańskiej zob. J.P. Reid, The Concept of Representation In the Age of the American Revolution, Chicago-London 1989, s. 97-109.

${ }^{54}$ Szerzej na ten temat podobnych powiązań i inspiracji Rousseau zob. M.C.J. Vile, Constitutionalism and the Separation of Powers..., s. 205, 211-212, 217-218.

${ }_{55}$ Zob. P. Bastid, Le gouvernement d'assemblée, op.cit., s. 135n; zob. także M.C.J. Vile, Constitutionalism and the Separation of Powers..., s. 208-210. 
FROM DIRECT DEMOCRACY TO THE GOUVERNEMENT D'ASSEMBLÉE?
ROUSSEAU AND THE PROBLEMS OF REPUBLICAN CONSTITUTIONALISM

\section{Summary}

The following article considers the problems connected with the relationship between the principles of the direct democracy and the gouvernement d'assemblée. The values contemporarily ascribed to these principles are often counted among different, sometimes even opposing, traditions of republican constitutionalism. However, the proposed analysis of Rousseau's thought suggests that the general intellectual tendencies that are attributed to both systems might originally have had a lot in common. Furthermore, they embody the two different republican ways of implementing the very ideas of popular sovereignty and the accountability of the public authorities to the citizens. The undertaken juxtaposition of the contents of the Social Contract and of the Considerations on the Government of Poland may even point to an evolution of Rousseau's stance. It can be discerned especially in the approval in the second work, which pertained to one of the largest European states of that time, as it conveys the need to shift the responsibility for law-making to the assembly of deputies (the Sejm). The proposition of transferring this responsibility to a quasi-representative body corresponds perfectly with the warnings against the abuses of an unchecked executive, which are equally stringent in the Social Contract. This actually denoted that Rousseau was ready to accept some sort of gouvernement d'assemblée in large states. In the end however, it did not mark a departure from the ideals of the direct government, especially after taking into consideration Rousseau's extraordinary appreciation of the institutions of deputy directives and - treated already as an emergency measure - confederation.

\section{DE LA DEMOCRATIE DIRECTE AU REGIME D’ASSEMBLEE? ROUSSEAU ET LES PROBLEMES DU CONSTITUTIONNALISME REPUBLICAIN}

\section{Résumé}

L'article présente une réflexion sur les problèmes des relations entre les idéaux de la démocratie directe et le système qu'on appelle le régime d'assemblé. Aujourd'hui, les principes spécifiques pour ces systèmes politiques font partie de différentes traditions du constitutionnalisme républicain, parfois même opposées.

Cependant, l'idéal de Rousseau, ici analysé, montre qu'au début, les tendances générales attribuées à ces modèles, présentant deux façons différentes de la mise en œuvre de la souveraineté républicaine du peuple et du contrôle civique des pouvoirs publics, pouvaient avoir de nombreux points en commun. La comparaison entre les œuvres : $D u$ Contrat social et Considérations sur le gouvernement de Pologne, effectuée à cet effet, peut même montrer l'évolution de la position de Rousseau. Elle se manifestait en particulier par l'approbation, dans ce deuxième œuvre consacré en effet à l'un des plus grands pays de l'Europe à cette époque-là, la nécessité d'existence des institutions qui transfère la responsabilité pour la législation aux assemblées parlementaires (Parlement). 
L'auteur des Considérations a inclus dans son œuvre la proposition de transfert du pouvoir de décisions publiques à des organismes quasi-représentatifs, qui corresponde parfaitement avec l'avertissement aussi forte, présenté dans Du Contrat social, contre l'abus du pouvoir exécutif sans contrôle. Cette proposition de Rousseau a témoigné en fait sa reconnaissance d'une espèce de régime d'assemblée dans les grands pays. En fin de compte, pourtant, cela ne signifiait pas l'abandon des idéaux de l'administration directe, compte tenu l'institution des instructions parlementaires si appréciée par Rousseau ainsi que des confédérations - traitées comme une mesure exceptionnelle. 